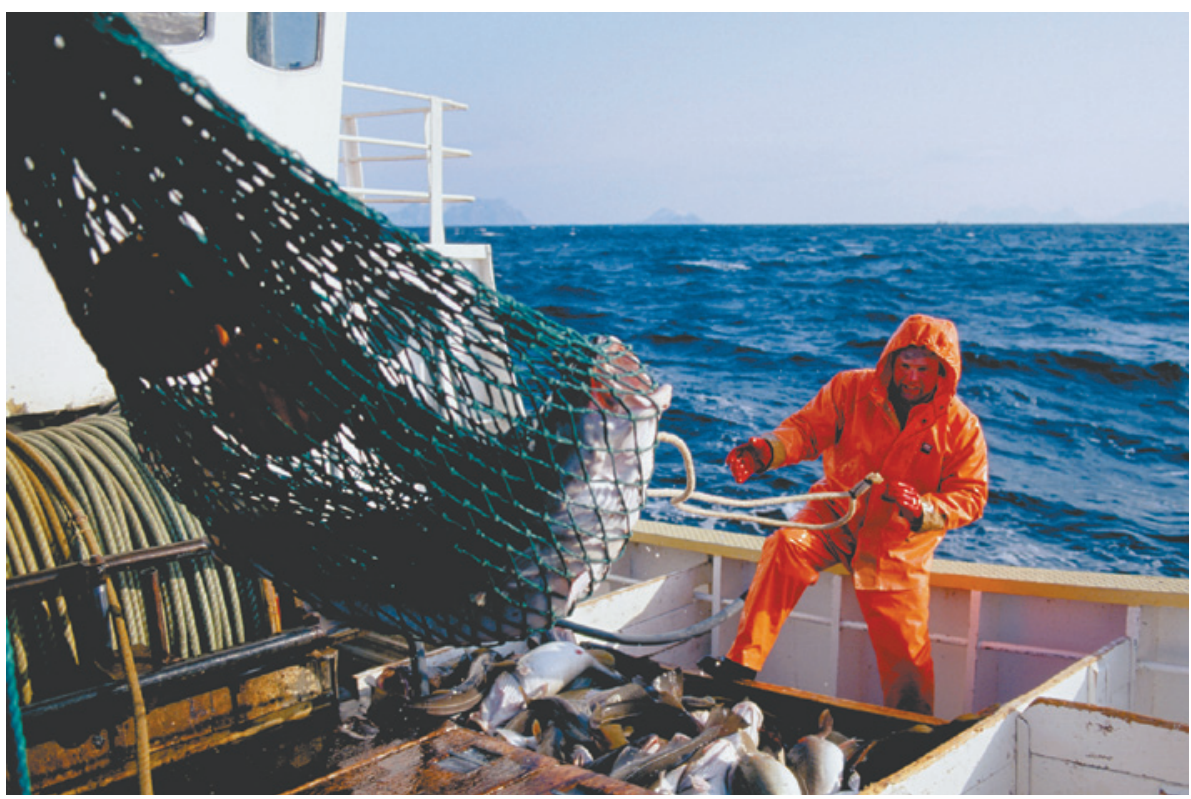

The fishing industry has been preparing for a key European parliamentary vote on subsidies.

FISHERIES POLICY

\title{
Europe debates fisheries funding
}

\section{Campaigners want subsidies to be focused on conservation.}

\section{BY DANIEL CRESSEY}

A s Nature went to press, the European Parliament was voting on how billions of euros in subsidies should be allocated to the fishing industry. In past years, the main focus has been on 'capacity building' the strengthening and support of fishing fleets. But now, after years of worries about overfishing and damage to the marine environment, calls are growing among scientists for more spending on sustainability and conservation.

The battle lines have been drawn. Some of the roughly $€ 6.4$ billion (US $\$ 8.7$ billion) in subsidies earmarked to support fishing between 2014 and 2020 - known as the European Maritime and Fisheries Fund - is slated to go to conservation and data collection. But, as in the past, much of the money could be spent on modernizing vessels, cutting fuel costs and even on the construction of fishing boats.

These measures would please fishermen but outrage conservation groups and some scientists, who fear that a vote by Members of the European Parliament (MEPs) to subsidize an increase in fishing capacity could undo work to put fishing on a more scientific footing. Europe has long been criticized for ignoring advice on safe levels of fishing, but this year the European
Union (EU) took a big step forward when it agreed a package of legislation to put science at the centre of all decisions on setting catch quotas (see Nature 498, 17-18; 2013). Voting for capacity-enhancing subsidies could undermine that achievement, campaigners argue.

Researchers also point out that Europe catches more fish than is sustainable in many areas. By the European Commission's own estimates,

\section{NET SPEND}

Researchers say that fisheries subsidizers allocate more to potentially harmful subsidies such as fuel than to 'beneficial' activities such as conservation.

- Beneficial: fisheries management and R\&D - Harmful: enhancing capacity of fishing fleets Unknown impact

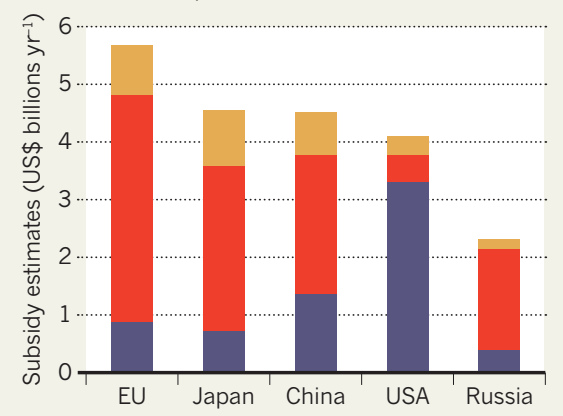

four-fifths of Mediterranean fish stocks and almost half of Atlantic stocks are overfished, leaving populations of species such as cod and mackerel in a bad way. Subsidizing fleets to boost catches could be devastating to ecosystems that are already under pressure, critics say.

Ahead of the vote, a campaign by researchers has challenged MEPs to amend the funding legislation so that subsidies instead go to better management and research, such as assessments of how many fish are in the seas, the setting up of marine reserves and basic oceanographic studies. More than 180 researchers have signed a letter urging MEPs to support this measure.

Rashid Sumaila, director of the Fisheries Economics Research Unit at the University of British Columbia in Vancouver, Canada, was one of the organizers of the letter and the lead author of a report submitted to Parliament last week. In it, he and his colleagues estimate that about $\$ 35$ billion is spent on subsidies globally each year, with capacity-enhancing subsidies making up more than $\$ 20$ billion of that (see go.nature.com/yxpfe2 and 'Net spend'). Sumaila and his colleagues want an end to payments that increase the ability of fishing fleets to catch fish, including those that cut fuel costs and fund the modernization of boats.

Sumaila admits that these recommendations will not "go down well" with politicians and fishermen. But, he says, "if sustainable fisheries are your goal, you need to cut the subsidies".

The vote is being watched closely. Some nations - notably New Zealand — have made moves to phase out damaging subsidies, but a similar global agreement has proved harder to achieve. Many countries, such as France and Spain, are wedded to subsidies, which they believe support a crucial food sector.

And the dispute could have repercussions for global trade. Fisheries subsidies are being discussed at the World Trade Organization, but those talks are deadlocked. The EU has repeatedly said that it supports the elimination of subsidies that contribute to overcapacity. A vote in the other direction now could make it harder to get global agreement. "On an international level, people are always watching the EU," says Markus Knigge, a policy expert at the Brussels-based European Marine Programme run by the Pew Charitable Trusts.

Once it has voted, the European Parliament will enter into negotiations with the European Council - made up of representatives of the EU's 28 member states. A final agreement on the subsidy package is expected early next year.

Ray Hilborn, a fisheries researcher at the University of Washington in Seattle, argues that Europe already has a well-developed management system for its fisheries. "If they would just keep the politicians out of quota setting, they would do pretty well," he says.

And, he adds, a properly managed fishery should not need subsidies: "If fisheries are well managed, they are very profitable and they should have to fend for themselves." - 